\title{
Regulatory lymphocytes: the dice that resolve the tumor endgame
}

\author{
Subhadip Pati, Anandi Chowdhury, Sumon Mukherjee, Aharna Guin, Shravanti Mukherjee and Gaurisankar Sa* (D)
}

\begin{abstract}
A large number of cancer patients relapse after chemotherapeutic treatment. The immune system is capable of identifying and destroying cancer cells, so recent studies have highlighted the growing importance of using combinatorial chemotherapy and immunotherapy. However, many patients have innate or acquired resistance to immunotherapies. Long-term follow-up in a pooled meta-analysis exhibited long-term survival in approximately $20 \%$ of patients treated with immune checkpoint inhibitors or the adoptive transfer of chimeric $T$ cells. It has been reported that high levels of immunoregulatory cells in cancer patients contribute to immunotherapy resistance via immunosuppression. Among the most important regulatory cell subtypes are the CD4 ${ }^{+}$T-regulatory cells (Tregs), identified by their expression of the well-characterized, lineage-specific transcription factor FOXP3. In addition to $\mathrm{CD}^{+}$Tregs, other regulatory cells present in the tumor microenvironment, namely CD8 ${ }^{+}$Tregs and IL10-producing B-regulatory cells (Bregs) that also modulate the immune response in solid and lymphoid tumors. These cells together have detrimental effects on tumor immune surveillance and anti-tumor immunity. Therefore, targeting these regulatory lymphocytes will be crucial in improving treatment outcomes for immunotherapy.
\end{abstract}

Keywords: Breg, CTLA4, FOXP3, Immunotherapy, IL10, PDL1, Treg

\section{Background}

The suppression of anti-tumor immune responses and augmentation of tumor-promoting immune responses both contribute to tumor progression [1]. The pioneering work of Sakaguchi et al. revealed the existence of Tregulatory cells (Tregs) that facilitate the development and maintenance of an immunosuppressive environment in the host [2]. The presence of these Tregs in the tumor microenvironment consistently maintains 'pro-tumor' conditions essential for the advancement of cancer [3]. Most conventional cancer immunotherapies involve the blockade of immune checkpoint molecules such as cytotoxic T-lymphocyte-associated protein-4 (CTLA4) and programmed death-1 and provide remarkable clinical efficacy across several cancers [4]. The clinical efficacy of immune checkpoint blockade therapy is visible in patients with tumors harbouring somatic mutation-derived

\footnotetext{
* Correspondence: gauri@jcbose.ac.in

Division of Molecular Medicine, Bose Institute, P1/12, C.I.T Scheme VII M, Kolkata 700054 , India
}

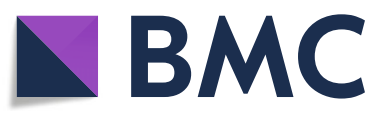

neo-antigens, which are not present in non-cancerous cells [5]. These neo-antigens offer a clinical advantage since the tumor cells expressing neo-antigens are then recognized as 'non-self' by the immune system, which then specifically targets and eliminates them while sparing the non-cancerous cells [6]. It is predicted that reducing the suppressive activity of Tregs has broad potential for cancer immunotherapy in patients with a low number of neo-antigens [7]. Most of the research in this field has concentrated on the immune-suppressive activity of $\mathrm{CD}^{+}{ }^{+}$Tregs [3]. However, unique combinations of cytokines and chemokines in the tumor microenvironment can influence the development of new and uncharacterized populations of immune cells [8].

FOXP3-expressing $\mathrm{CD}^{+}$Tregs have also started to gain importance in this regard. Data suggest that the presence of these cells might be a marker of positive clinical outcome for cancer patients [9]. These $\mathrm{CD} 8^{+}$ Tregs also have immunosuppressive activity, like their $\mathrm{CD} 4^{+}$counterparts, through various mechanisms including cell to cell contact, secretion of cytokines (such as

(c) The Author(s). 2020 Open Access This article is licensed under a Creative Commons Attribution 4.0 International License, which permits use, sharing, adaptation, distribution and reproduction in any medium or format, as long as you give appropriate credit to the original author(s) and the source, provide a link to the Creative Commons licence, and indicate if changes were made. The images or other third party material in this article are included in the article's Creative Commons licence, unless indicated otherwise in a credit line to the material. If material is not included in the article's Creative Commons licence and your intended use is not permitted by statutory regulation or exceeds the permitted use, you will need to obtain permission directly from the copyright holder. To view a copy of this licence, visit http://creativecommons.org/licenses/by/4.0/. 
TGF $\beta$, IL16, IL10, CCL4), and initiating tolerogenic phenotype in antigen-presenting cells $[10,11]$.

Recent research in B-cell biology has found a novel IL10-producing subset of B cells that modulates tumor immune responses. This population has been designated as B-regulatory cells (Bregs), which play a significant role in the harmonization of immune responses involved in autoimmunity, inflammation, and cancer [12]. Bregs generally suppress other cells, including $\mathrm{T}$ cells through secretion of the anti-inflammatory cytokine IL10, and they can also facilitate the conversion of T-effecter cells into Tregs, thus attenuating anti-tumor immune responses. Bregs have also been found to be recruited to the tumor microenvironment to acquire immunosuppressive properties and thereby mitigate anti-tumor immune responses [13]. This review emphasizes regulatory cell-mediated immunosuppressive mechanisms in cancer and the possibility for Treg-/Breg-targeted cancer immunotherapy, leading to a promising clinical efficacy as demonstrated in several preclinical studies as well as in early-phase clinical studies.

\section{$\mathrm{CD}^{+}$Tregs}

The most common and well-known regulatory lymphocyte is the $\mathrm{CD}^{+}$Treg [14]. There are two forms of $\mathrm{CD}_{4}^{+}$Tregs, both expressing the transcription factor fork-head box-p3 (FOXP3): naturally occurring $\mathrm{CD} 4{ }^{+} \mathrm{CD} 25^{+}$Tregs (nTregs) in the thymus constitutively express FOXP3 while induced Tregs (iTregs) in the periphery are induced to express FOXP3 [14]. iTregs can be further divided into two subtypes depending on the expression of immunosuppressive molecules, namely the IL10-producing Treg type-1 (Tr1) cells and the TGF $\beta-$ producing Th3 cells [15]. nTregs actively participate in the maintenance of immunological self-tolerance and immune homeostasis [16]. Both nTregs and iTregs are categorized by increased levels of CD25, FOXP3, CTLA4, and glucocorticoid-induced tumor necrosis factor-related receptor (GITR). But unlike nTregs, iTregs show lower expression of CD73 and programmed cell death protein-1 (PD), and higher expression of the transcription factor Helios and the surface antigen neuropilin-1 (Nrp1) [17].

Expression of the immunoglobulin-like transmembrane protein lymphocyte-activation gene 3 together with ATP-degrading enzymes CD39 and CD73 on the surface of Tregs might help to enhance the suppressive activity of Tregs (Fig. 1). These ATP-degrading enzymes control the pro-inflammatory state of the tumor microenvironment by a negative-feedback mechanism $[18,19]$. Lymphocyte-activation gene 3 expression leads to reduced calcium signaling and thus reduced cytokine production, preventing immune responses [18], whereas enhanced ATP generation in the pathological state results in high levels of AMP and adenosine and an antiinflammatory state [19]. Granzyme B-producing tumorinduced Tregs are among the major players underlying the suppression of tumor clearance by blocking natural killer and $\mathrm{CD}^{+} \mathrm{T}$ cell activity [20].

In most human cancers, IL10 secreted from Tregs in the tumor microenvironment is controlled by the transcription factor FOXP3 in association with signal transducer and activator of transcription-3 [21]. These immunosuppressive cells have been associated with poor cancer prognosis [22]. Besides IL10, Tregs are also known to secrete TGF $\beta$, which inhibits effector $\mathrm{T}$ cells and creates an immunosuppressive environment [14]. There is ample evidence on the impact of Treg depletion on human tumor progression. One study demonstrated that patients with hepatocellular carcinoma contain a higher number of suppressive $\mathrm{CD} 4^{+} \mathrm{CD} 25^{+} \mathrm{FOXP} 3^{+}$ Tregs, and depleting this population by blocking surface receptors like CTLA4, CD25, or various chemokine receptors could enhance anti-tumor immunity [23, 24].

Interestingly, some chemotherapeutic agents (including aromatase inhibitors, cyclophosphamide, fludarabine, gemcitabine, mitoxantrone, anti-GITR, or anti-OX40 antibodies) also reduce Tregs in addition to their wellknown tumor-regressing effects $[25,26]$. Another study identified mitogen-activated protein kinase kinase (MEK)/extracellular signal-regulated kinase (ERK)-signaling as a potential target for reversing Treg augmentation in breast cancer patients [27]. Moreover, many reports have shown that blockade of chemokine signaling can reduce the migration of Tregs to the tumor site; hence, targeting chemokine ligands with antibodies could significantly deplete Tregs and produce an antitumor response [28]. The anti-receptor activator of nuclear factor-kappa B ligand (RANKL) antibody denosumab may be useful in inhibiting Treg-mediated metastasis of various tumors via inhibition of RANK signaling [29]. Similarly, increased COX-2 expression is a distinctive feature of the tumor environment, and many COX-2 inhibitors have been shown to reduce Treg numbers [30]. Further in-depth studies are needed to identify a potent, targetable $\mathrm{CD} 4^{+}$Treg marker to modulate their tumor-promoting role in a clinical scenario.

\section{$\mathrm{CD}^{+}$Tregs}

In contrast to conventional $\mathrm{CD}^{+} \mathrm{T}$ lymphocytes that impart a cytotoxic mode of action in the body by acting against various antigens without clonal exhaustion, $\mathrm{CD}^{+}$Tregs play a role in suppressing this immune response to prevent an aggravated reaction while establishing homeostasis of the body's immune system [31]. They also help to protect the body from autoimmune diseases, inflammatory diseases, and transplantation [32]. The 

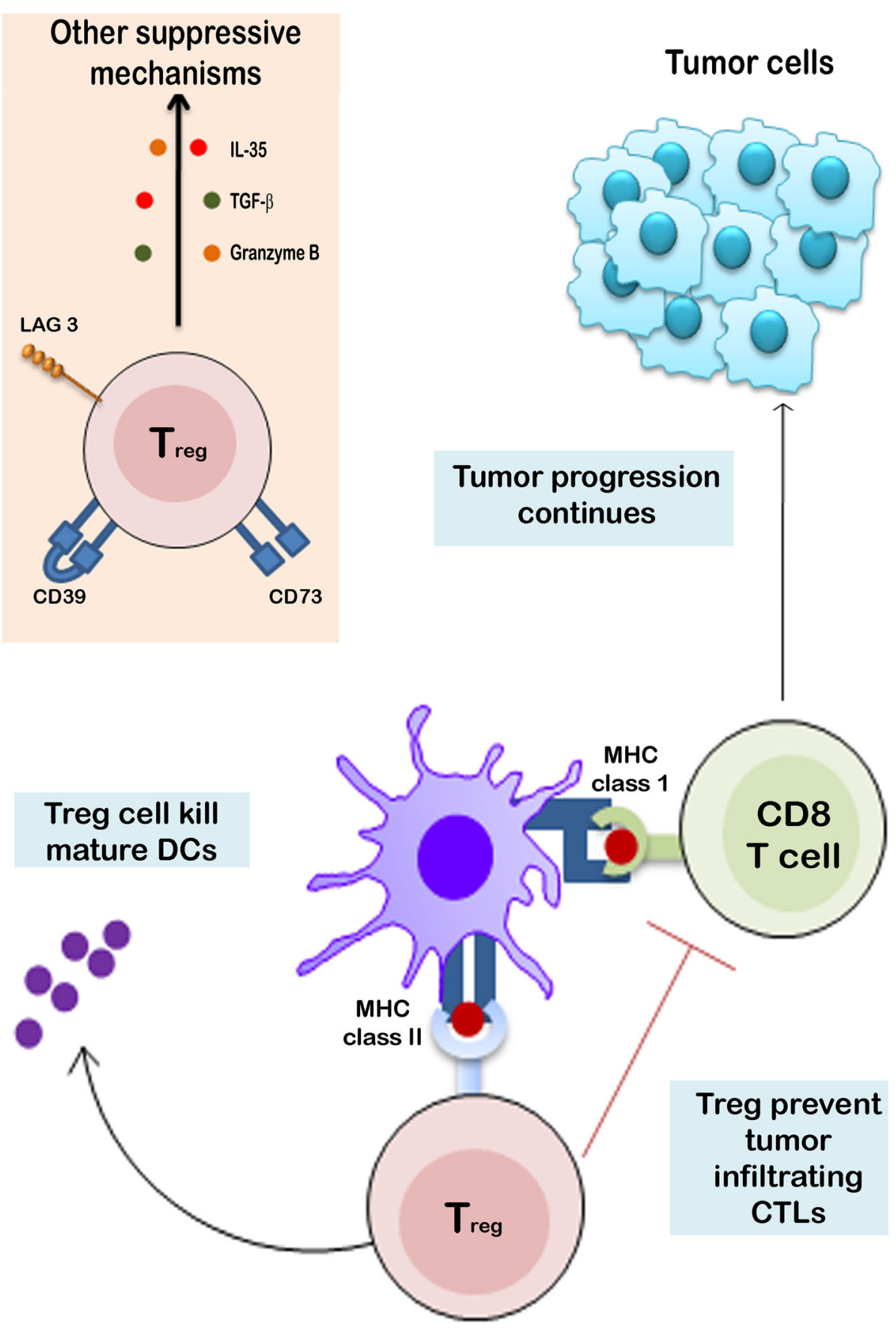

Fig. 1 Mechanisms underlying Treg immune regulation in the tumor-microenvironment. Tregs express a unique complement of immunosuppressive molecules on their surfaces, including lymphocyte-activation gene-3 and ATP- and AMP-degrading enzymes. They also secrete immune regulatory modulators (such as granzyme B) and cytokines (IL10, TGF $\beta$ etc.), by which they can negatively regulate dendritic cells as well as cytotoxic $T$ cells thereby facilitating tumor initiation and progression

year 1970 was marked by the discovery of regulatory $\mathrm{CD}^{+} \mathrm{T}$ cells by Gershon and Kondo [33].

Research has identified FOXP3 expression as the most profound marker of T-regulatory lymphocutes [34]. FOXP3 (also known as scurfin) is a member of the forklike transcription factor family identified in 2001 by
Brunkow et al. as the master regulator for T-cell differentiation and function [35]. In humans, FOXP3 has been observed to be expressed in $\mathrm{CD} 4{ }^{+} \mathrm{CD} 25^{+} \mathrm{T}$ cells and $\mathrm{CD}^{+} \mathrm{T}$ lymphocytes; in mice, FOXP3 expression in $\mathrm{CD}^{+} \mathrm{T}$ lymphocytes is limited [36]. Though there has long been a dearth of reliable markers to correctly 
identify $\mathrm{CD}^{+}$Tregs from regular $\mathrm{CD}^{+} \mathrm{T}$ lymphocytes, FOXP3 proves to be the most promising [37]. $\mathrm{CD}^{+}$ Tregs could also be characterized by levels of CD25 and CD127 [38]. Other phenotypic and functional markers of $\mathrm{CD}^{+}$Tregs include elevated expression of CD94, NKG2a, Ki-67, CTLA4, and ICOS as compared to conventional $\mathrm{CD}^{+} \mathrm{T}$ cells $[39,40]$. Markers such as CD45RA and CD62L with minor or negative expression of CD45RO, CD27, CD28, and CCR7 can also be used for better characterization of $\mathrm{CD}^{+}$Tregs [39]. Studies of $\mathrm{CD}^{+} \mathrm{CD}_{2} 5^{+} \mathrm{FOXP}^{+}$Tregs in humans with IL2 stimulation in vitro and in vivo have presented promising results in support of the high suppressive property of these cells [40].

A prevalence of a distinct subset of $\mathrm{CD} 8^{+}$Tregs has been reported in colon cancer $\left(\mathrm{CD} 8^{+} \mathrm{CD} 25^{+} \mathrm{FOXP} 3^{+}\right.$ cells), ovarian cancer $\left(\mathrm{CD} 8^{+} \mathrm{CCR} 7^{+} \mathrm{IL} 10^{+}\right)$, prostate cancer $\left(\mathrm{CD}^{+} \mathrm{CD}^{-} 8^{-}\right)$, and non-small cell lung cancer $\left(\mathrm{CD} 8^{+} \mathrm{CD} 28^{-}\right)$[41-45]. Neutralization and proliferation studies in ovarian cancer suggest that in-vitro induction of $\mathrm{CD}^{+}$Tregs depends partially on TGF $\beta 1$ activation of the p38MAPK-signaling pathway, suggesting that p38MAPK could be targeted by anti-cancer immunotherapy to treat ovarian cancer [44].

Previous studies have shown that an expansion of $\mathrm{CD} 8^{+} \mathrm{CD} 28^{-}$Treg lymphocytes in cancer patients may be associated with disease advancement and poor survival. $\mathrm{CCR}^{+} \mathrm{CD}^{2} 5 \mathrm{RO}^{+} \mathrm{CD}^{+}$Tregs down-regulate the functionality of T-effector cells that act against tumor antigens in the body via IL10 secretion [46]. Thus, therapeutic strategies to alter tumor Treg infiltration could be beneficial for patient survival [47]. It has been observed that decreasing $\mathrm{CD}^{+} \mathrm{FOXP}^{+}$Treg levels in the microenvironment of prostate cancer may increase the efficiency of immunotherapy [34]. Research on ovarian cancer shows that while the cancer progresses from benign to malignant form, levels of $\mathrm{CD}^{+}$Tregs increase along with expression of CD25, FOXP3, and CTLA4, and CD28 expression is reduced, in both peripheral circulation and the intra-tumoral microenvironment [42]. $\mathrm{CD} 8^{+} \mathrm{CD} 28^{-} \mathrm{T}$ lymphocytes have been known to inhibit $\mathrm{CD} 4^{+} \mathrm{T}$-helper cell functionality via secretion of various inhibitory cytokines, including IL10, IL16, and TGF $\beta$ or cell-to-cell contact [10, 11, 48].

According to antigen stimulation studies, $\mathrm{CD}^{+}{ }^{+}$Tregs can be classified into various subtypes [49]. First, alloantigen-specific $\mathrm{CD} 8^{+} \mathrm{CD} 28^{-}$Treg lymphocytes are generated by MHC class-I stimulation of a peptide expressing a different isoform of FOXP3 (FOXP3 $\alpha$ ). This subset increases expression of the negative costimulatory receptors immunoglobulin-like transcripts- 3 and -4 and downregulates expression of the positive costimulatory molecules CD80 and CD86 on antigen presenting cells, thus supporting a tolerogenic phenotype [34, 50, 51].
Second, Qa-1-specific CD8 ${ }^{+}$Tregs are uniquely formed by the induction of Qa-1/peptide complexes that are expressed on $\mathrm{CD}^{+} \mathrm{T}$ cells after vaccination with myelin basic protein. They characteristically recognize activated $\mathrm{CD}^{+} \mathrm{T}$ cells expressing Qa-1 molecules, thereby sustaining immune tolerance via eradication of these auto-recognizing cells $[52,53]$. Third, $\mathrm{CD} 8^{+} \mathrm{CD} 25^{+}$Tregs express markers such as FOXP3, GITR, and CD122, and are similar $\mathrm{CD}_{4}^{+}$Tregs in that they can inhibit the expansion of naïve $\mathrm{CD} 4^{+}, \mathrm{CD}^{+}$, and effector $\mathrm{T}$ lymphocytes $[54,55]$. Finally, $\gamma \delta$-T cell receptor-expressing Tregs recognize a few peptide antigens unaccompanied by MHC class-I and -II molecules and thus play an important role in immunosurveillance during cancer progression [56]. These cells are known to down-regulate conventional $\mathrm{T}$-lymphocyte proliferation and dendritic cell maturation [57].

\section{B-regulatory cells}

B lymphocytes represent an essential component of adaptive immunity as they positively regulate immune responses through the production of immunoglobulins and also act as immune modulators by presenting antigen to $\mathrm{T}$ cells through the secretion of cytokines. In the context of a tumor, B cells act as a double-edged sword: the conventional $\mathrm{B}$ cell facilitates tumor regression, whereas Bregs aid tumor progression [58]. The role of B cells in immune-specific suppression was first described in 1974 in the context of delayed-type hypersensitivity reactions. Later on, the suppressive activity of B cells was also demonstrated in a model of experimental autoimmune encephalomyelitis [59]. Mizoguchi and colleagues were the first to use the term regulatory B cell to designate those having an immunosuppressive nature [60]. The main characteristic that differentiates Bregs is the production of IL10. In addition to expressing IL10, Bregs also express other immune-regulatory cytokines such as TGF $\beta$ and IL35 [61]. Currently, multiple Breg cell subsets with many similarities in phenotype and effector functions have been described: $\mathrm{CD} 19^{+} \mathrm{CD} 24^{\mathrm{hi}} \mathrm{CD} 38^{\text {hi }}$ transitional B cells, CD $35^{+} \mathrm{CD} 80^{-}$ $\mathrm{B}$ cells, transitional-2 marginal-zone precursor (T2MZP) cells, $\mathrm{CD}^{+} \mathrm{CD} 1 \mathrm{~d}^{\mathrm{hi}} \mathrm{B}$ (B10) cells, marginal zone (MZ) B cells, and Tim $1^{+} \mathrm{B}$ cells $[58,62]$.

However, the precise stage of Breg differentiation at which they acquire their regulatory capacity remains unknown. B cells mature and differentiate into antibodyproducing memory and plasma cells after encountering conventional $\mathrm{T}$ cells or cytokines secreted by $\mathrm{T}$ cells. This interaction may occasionally give rise to a generation of highly-suppressive Bregs [58] due to influence of an environmental factor that has yet to be identified (Fig. 2). Various Breg subtypes have been found in high numbers in several types of tumors, in which they 


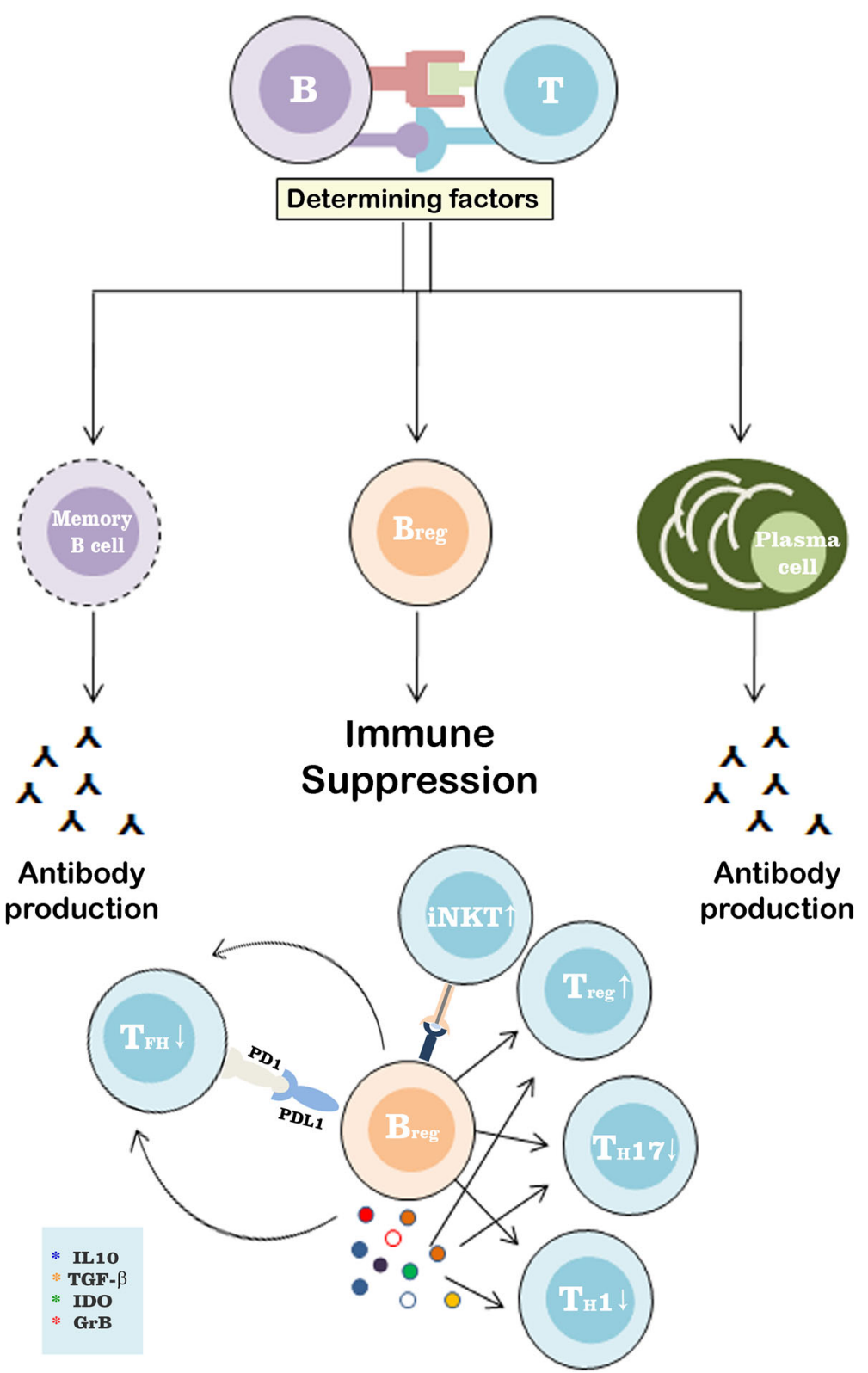

Fig. 2 The possible developmental sketch of Breg generation and the different functions played by this immunoregulatory subset of B cells. The interaction between conventional B and T cells can give rise to memory and plasma B cells whose primary function is to produce antibodies to fight against tumor antigens. This interaction might also give rise to immunosuppressive Bregs, which generally suppress Th1, Th17, and follicular helper T cells with the help of immunoregulatory modulators such as IL10, TGF $\beta$, indoleamine 2,3-dioxygenase, and granzyme B

attenuate local anti-tumor immune responses through several mechanisms and hence promote tumor progression $[63,64]$. Bregs reduce anti-tumor responses by inhibiting the proliferation and function of conventional $\mathrm{T}$ cells, especially $\mathrm{T}$ helper (Th) 1, Th17 (Fig. 2), and follicular helper T cells [59] as well as macrophages, DCs, natural killer cells, and natural killer $\mathrm{T}$ cells by contactdependent or independent mechanisms [65-67]. Transitional Bregs $\left(\mathrm{CD} 24^{\mathrm{hi}} \mathrm{CD} 38^{\mathrm{hi}}\right)$ stimulated with $\mathrm{CD} 40$ have been shown to produce higher levels of IL10, thus reducing the expression of CD86. As a result, the proliferation of $\mathrm{T}$ cells and production of tumor necrosis factor- $\alpha$ decrease [68]. Similar to Tregs, Bregs can suppress follicular helper $\mathrm{T}$ cells through the expression of programmed death ligand-1 (PDL1) in a contactdependent manner, which leads to indirect inhibition of humoral responses [69]. Another population of Bregs identified in patients with solid tumors produce 
granzyme B when stimulated with IL21 and can suppress $\mathrm{CD}^{+} \mathrm{T}$ cell proliferation through degradation of the $\mathrm{T}$ cell receptor $\zeta$-chain (Fig. 2) [70].

Olkhanud et al. demonstrated that tumor-evoked Bregs play a significant role in tumor growth and metastasis by converting T-effector cells into Tregs [71]. Human glioma cells secrete phosphatidylinositol-glycan biosynthesis class $\mathrm{F}$ protein, which may play a role in mediating conversion of $\mathrm{B}$ cells into a regulatory phenotype and increasing differentiation of Bregs [72]. Studies

\section{Regulatory lymphocytes depletion from total lymphocyte pool}
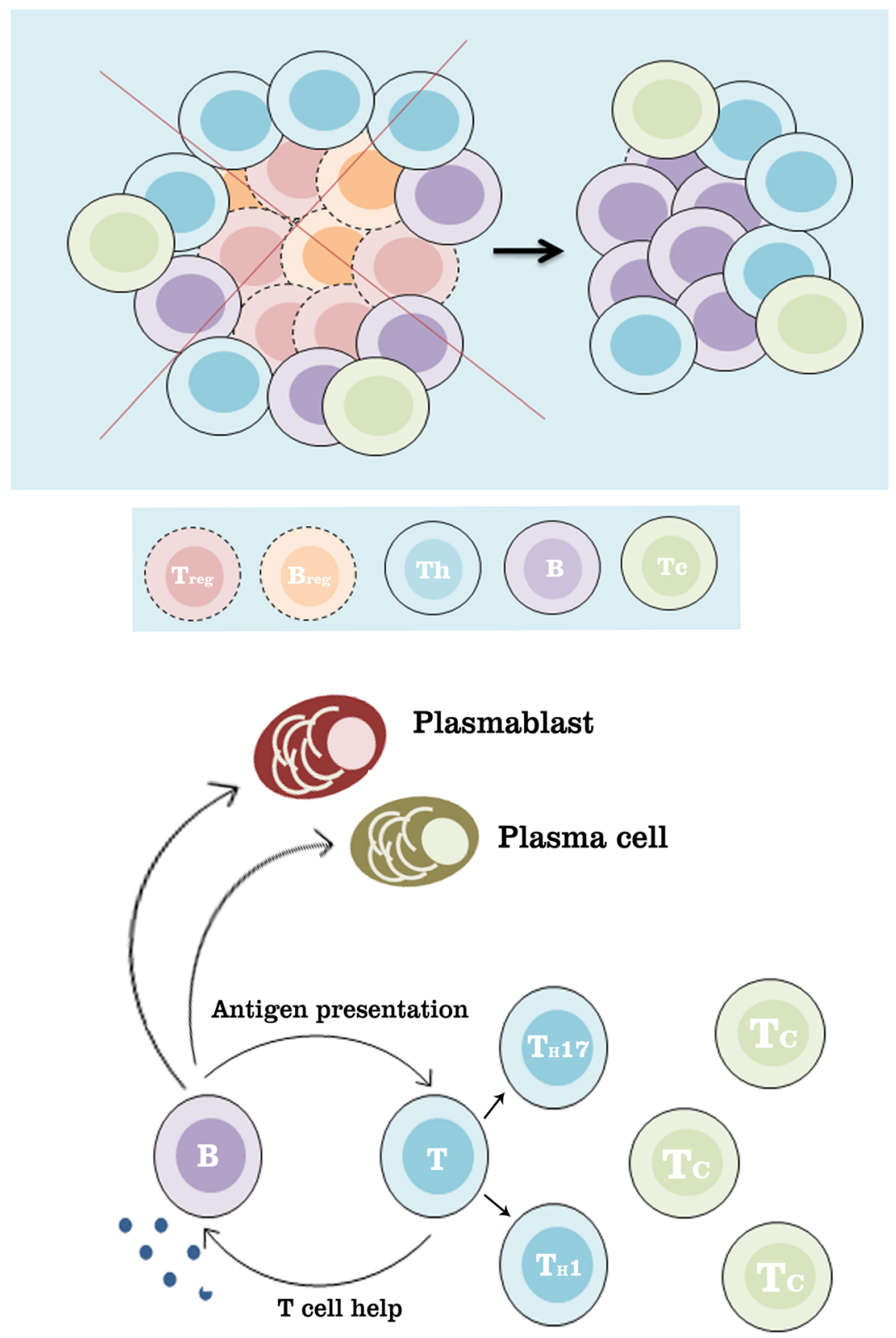

\section{Sketch of newly reformed lymphocytes after the depletion therapy}

Fig. 3 Proposed mechanism of regulatory lymphocyte depletion therapy in the tumor. The model for depletion therapy suggests that by reducing Breg and Treg populations in the tumor microenvironment, B cells would be allowed to branch into plasmablast and plasma cells while T cells would differentiate into Th1 and Th17 cells. These differentiated B and T cells would, in turn, inhibit tumor cell growth and ultimately disrupt cancer progression 
show that during the progression of a tumor, Breg numbers increase, leading to secretion of large amounts of IL10, TGF $\beta$, indoleamine 2,3-dioxygenase, and induction of PDL1 expression which together lead to complete immune disruption (Fig. 2) [73]. Some reports suggest that CD20 ${ }^{\text {low }} 4-1 \mathrm{BBL}^{\text {low }}$ immune-suppressive Breg is responsible for the failure of the immunotherapeutic drug rituximab, and $\operatorname{IgA}^{+} \mathrm{CD} 138^{+} \mathrm{PDL1}^{+} \mathrm{IL} 10^{+}$Breg for the failure of the chemotherapeutic drug oxaliplatin [63]. The depletion of $\mathrm{CD} 20^{+}$B cells with anti-CD20 antibodies results in higher numbers of Bregs in tumorbearing mice [74].

\section{Conclusions}

After considering the evidence of many studies, this review summarizes how regulatory lymphocytes hamper the host immune response against various tumor antigens. These tumor-specific immunosuppressive cells also increase the metastatic progression of tumors by enhancing $\mathrm{T}$ cell-mediated suppression. They mask anti-tumor immune responses and are more effective in the absence of tumor-infiltrating conventional $\mathrm{T}$ and $\mathrm{B}$ cells. Although the potential immunosuppressive properties of these cells have not been adequately studied, significant advances in the understanding of regulatory cell biology have been made in recent years that have provided valuable insight to this relatively less explored area of tumor immunotherapy. Successful depletion of $\mathrm{CD}^{+}$Treg, $\mathrm{CD}^{+}$Treg, and $\mathrm{CD}^{+} 9^{+}$Breg populations from the tumor microenvironment may lead to the branching of effector T and B cells into Th1 and Th17 lympocytes, plasmablasts and plasma cells (Fig. 3). These differentiated $\mathrm{B}$ and $\mathrm{T}$ cells would then in turn inhibit tumor growth. Thus, better characterization of $\mathrm{T}$ - and $\mathrm{B}-\mathrm{regu}$ latory immune subsets and detailed mapping of their immune inhibitory properties is of utmost importance. A better understanding of their complex fundamental mechanisms can pave the way for better targeting of these cells for more efficient and successful tumor immunotherapy.

\section{Abbreviations}

Breg: B-regulatory cell; CCR: Chemokine receptor; COX2: Cyclooxygenase-2; CTLA4: Cytotoxic T lymphocyte-associated antigen-4; FOXP3: Fork-head box P3; GITR: Glucocorticoid-induced tumor necrosis factor receptor-related protein; IL: Interleukin; PDL1: Programmed death-ligand-1; TGF $\beta$ : Transforming growth factor- $\beta$; Th: T helper; Treg: T-regulatory cell

\section{Acknowledgments}

This work was supported from research grants from the SERB, Department of Science and Technology, Government of India.

\section{Authors' contributions}

SP undertook the background literature study and prepared the initial draft of the manuscript and the figures; AC contributed in literature study; SM helped in making the figures and arranging the references; AG contributed in extending the initial draft. SM helped in compiling the manuscript technical corrections to the draft; GS supervised the entire project and made final corrections to the draft. The author(s) read and approved the final manuscript.

\section{Funding}

This work was supported by research grants Department of Biotechnology, and Science \& Engineering Research Board, Department of Science \&

Technology, Government of India.

\section{Availability of data and materials}

Not applicable.

\section{Ethics approval and consent to participate}

Not applicable.

\section{Consent for publication}

All authors read and approved the final manuscript and concur with the submission for the publication.

\section{Competing interests}

The authors declare that they have no competing interests.

Received: 3 April 2019 Accepted: 23 June 2020

Published online: 07 July 2020

\section{References}

1. Wang $Y, M a Y$, Fang $Y$, Wu S, Liu L, Fu D, et al. Regulatory $T$ cell: protection for tumor cells. J Cell Mol Med. 2012;16(3):425-36.

2. Hori S, Nomura T, Sakaguchi S. Control of regulatory T cell development by the transcription factor Foxp3. Science. 2003;299:1057-61.

3. Ha T-Y. The role of regulatory T cells in cancer. Immune Netw. 2009:9(6): 209-35.

4. Seidel JA, Otsuka A, Kabashima K. Anti-PD-1 and anti-CTLA-4 therapies in cancer: mechanisms of action, efficacy, and limitations. Front Oncol. 2018;8:86

5. Yi M, Qin S, Zhao W, Yu S, Chu Q, Wu K. The role of neoantigen in immune checkpoint blockade therapy. Exp Hematol Oncol. 2018;7:28.

6. Wirth TC, Kühnel F. Neoantigen targeting-dawn of a new era in cancer immunotherapy? Front Immunol. 2017;19(8):1848.

7. Darvin P, Toor SM, Sasidharan Nair V, Elkord E. Immune checkpoint inhibitors: recent progress and potential biomarkers. Exp Mol Med. 2018; 50(12): 165 .

8. Nagarsheth N, Wicha MS, Zou W. Chemokines in the cancer microenvironment and their relevance in cancer immunotherapy. Nat Rev Immunol. 2017:17(9):559-72

9. Singh RP, La Cava A, Wong M, Ebling F, Hahn BH. CD8+ T cell-mediated suppression of autoimmunity in a murine lupus model of peptide-induced immune tolerance depends on Foxp3 expression. J Immunol. 2007;178: 7649-57.

10. Huff WX, Kwon JH, Henriquez M, Fetcko K, Dey M. The evolving role of CD8+CD28-immunosenescent T cells in cancer immunology. Int J Mol Sci. 2019;20(11):2810.

11. Klimiuk PA, Goronzy JJ, Weyand CM. IL-16 as an anti-inflammatory cytokine in rheumatoid synovitis. J Immunol. 1999:162:4293-9.

12. DiLillo DJ, Matsushita T, Tedder TF. B10 cells and regulatory B cells balance immune responses during inflammation, autoimmunity, and cancer. Ann N Y Acad Sci. 2010;1183:38-57.

13. Sarvaria A, Madrigal JA, Saudemont A. B cell regulation in cancer and antitumor immunity. Cell Mol Immunol. 2017;14(8):662-74.

14. Weiner HL. Induction and mechanism of action of transforming growth factor-beta-secreting Th3 regulatory cells. Immunol Rev. 2001;182:207-14.

15. Zeng $H$, Zhang $R$, Jin $B$, Chen $L$. Type 1 regulatory $T$ cells: a new mechanism of peripheral immune tolerance. Cell Mol Immunol. 2015;12:566-71.

16. Sakaguchi S. Naturally arising CD4+ regulatory t cells for immunologic selftolerance and negative control of immune responses. Annu Rev Immunol. 2004;22:531-62.

17. Jørgensen N, Persson G, Hviid TVF. The tolerogenic function of regulatory $T$ cells in pregnancy and cancer. Front Immunol. 2019;10:911.

18. Andrews LP, Marciscano AE, Drake CG, Vignali DAA. LAG3 (CD223) as a cancer immunotherapy target. Immunol Rev. 2017;276:80-96.

19. Antonioli L, Pacher P, Vizi ES, Haskó G. CD39 and CD73 in immunity and inflammation. Trends Mol Med. 2013;19(6):355-67. 
20. Cao X, Cai SF, Fehniger TA, Song J, Collins LI, Piwnica-Worms DR, Ley TJ. Granzyme B and perforin are important for regulatory $T$ cell-mediated suppression of tumor clearance. Immunity. 2007;27(4):635-46.

21. Hossain DMS, Panda AK, Manna A, Mohanty S, Bhattacharjee P, Bhattacharyya $S$, et al. FoxP3 acts as a cotranscription factor with STAT3 in tumor-induced regulatory T cells. Immunity. 2013;39(6):1057-69.

22. Sun L, Xu G, Liao W, Yang H, Xu H, Du S, Zhao H, Lu X, Sang X, Mao Y. Clinicopathologic and prognostic significance of regulatory $T$ cells in patients with hepatocellular carcinoma: a meta analysis. Oncotarget. 2017; 8(24):39658-72.

23. Unitt E, Rushbrook SM, Marshall A, Davies S, Gibbs P, Morris LS, et al. Compromised lymphocytes infiltrate hepatocellular carcinoma: the role of Tregulatory cells. Hepatol Baltim Md. 2005;41(4):722-30.

24. Shevach EM. Mechanisms of foxp3+ T regulatory cell-mediated suppression. Immunity. 2009:30(5):636-45.

25. Bracci L, Schiavoni G, Sistigu A, Belardelli F. Immune-based mechanisms of cytotoxic chemotherapy: implications for the design of novel and rationalebased combined treatments against cancer. Cell Death Differ. 2014;21(1):15-25.

26. Ko K, Yamazaki S, Nakamura K, Nishioka T, Hirota K, Yamaguchi T, et al, Treatment of advanced tumors with agonistic anti-GITR mAb and its effects on tumor-infiltrating Foxp3+CD25+CD4+ regulatory T cells. J Exp Med. 2005;202(7):885-91.

27. Hossain DMS, Panda AK, Chakrabarty S, Bhattacharjee P, Kajal K, Mohanty S, et al. MEK inhibition prevents tumour-shed transforming growth factor- $\beta$ induced T-regulatory cell augmentation in tumour milieu. Immunology. 2015;144(4):561-73.

28. Tan MCB, Goedegebuure PS, Belt BA, Flaherty B, Sankpal N, Gillanders WE, et al. Disruption of CCR5-dependent homing of regulatory $T$ cells inhibits tumor growth in a murine model of pancreatic cancer. J Immunol Baltim Md 1950. 2009;182(3):1746-55.

29. Tan W, Zhang W, Strasner A, Grivennikov S, Cheng JQ, Hoffman RM, et al. Tumour-infiltrating regulatory $T$ cells stimulate mammary cancer metastasis through RANKL-RANK signalling. Nature. 2011;470(7335):548-53.

30. Sharma S, Yang S-C, Zhu L, Reckamp K, Gardner B, Baratelli F, et al. Tumor cyclooxygenase-2/prostaglandin E2-dependent promotion of FOXP3 expression and CD4+ CD25+ T regulatory cell activities in lung cancer Cancer Res. 2005;65(12):5211-20.

31. Zhang N, Bevan MJ. CD8(+) T cells: foot soldiers of the immune system. Immunity. 2011;35(2):161-8.

32. Bézie S, Anegon I, Guillonneau C. Advances on CD8+ Treg cells and their potential in transplantation. Transplantation. 2018;102(9):1467-78.

33. Gershon RK, Kondo K. Cell interactions in the induction of tolerance: the role of thymic lymphocytes. Immunology. 1970;18(5):723-37.

34. Yu Y, Ma X, Gong R, Zhu J, Wei L, Yao J. Recent advances in $\mathrm{CD}^{+}$ regulatory $T$ cell research. Oncol Lett. 2018;15(6):8187-94.

35. Brunkow ME, Jeffery EW, Hjerrild KA, Paeper B, Clark LB, Yasayko SA, Wilkinson JE, Galas D, Ziegler SF, Ramsdell F. Disruption of a new forkhead/ winged-helix protein, scurfin, results in the fatal lymphoproliferative disorder of the scurfy mouse. Nat Genet. 2001;27(1):68-73.

36. Bin Dhuban K, Kornete M, Mason SE, Piccirillo CA. Functional dynamics of Foxp3 $^{+}$regulatory T cells in mice and humans. Immunol Rev. 2014;259:140-58.

37. Jebbawi F, Fayyad-Kazan H, Merimi M, Lewalle P, Verougstraete JC, Leo O, Romero $\mathrm{P}$, Burny A, Badran B, Martiat $\mathrm{P}$, Rouas R. A microRNA profile of human $\mathrm{CD} 8(+)$ regulatory $T$ cells and characterization of the effects of microRNAs on Treg cell-associated genes. J Transl Med. 2014:12:218.

38. Cosmi L, Liotta F, Lazzeri E, Francalanci M, Angeli R, Mazzinghi B, Santarlasci V, Manetti R, Vanini V, Romagnani P, Maggi E, Romagnani S, Annunziato F. Human CD8+CD25+ thymocytes share phenotypic and functional features with CD4+CD25+ regulatory thymocytes. Blood. 2003;102(12):4107-14.

39. Hu D, Weiner HL, Ritz J. Identification of cytolytic CD161- CD56+ regulatory CD8 T cells in human peripheral blood. PLoS One. 2013;8(3):59545.

40. Churlaud G, Pitoiset F, Jebbawi F, Lorenzon R, Bellier B, Rosenzwajg M, Klatzmann D. Human and mouse CD8(+)CD25(+)FOXP3(+) regulatory T cells at steady state and during interleukin-2 therapy. Front Immunol. 2015;6:171.

41. Chaput $\mathrm{N}$, et al. Identification of CD8+CD25+Foxp3+ suppressive T cells in colorectal cancer tissue. Gut. 2009:58:520-9.

42. Zhang S, et al. Analysis of CD8+ Treg cells in patients with ovarian cancer: a possible mechanism for immune impairment. Cell Mol Immunol. 2015a;12: 580-91.

43. Kiniwa $Y$, et al. CD8+Foxp3+ regulatory $T$ cells mediate immunosuppression in prostate cancer. Clin Cancer Res. 2007a;13:6947-58.
44. Sfanos KS, De Marzo AM. Prostate cancer and inflammation: the evidence. Histopathology. 2012;60(1):199-215.

45. Chen C, et al. Changes of CD4+CD25+FOXP3+ and CD8+CD28- regulatory $T$ cells in non-smallcell lung cancer patients undergoing surgery. Int Immunopharmacol. 2014;18:255-61.

46. Song G, Wang X, Jia J, Yuan Y, Wan F, Zhou X, et al. Elevated level of peripheral CD8(+)CD28(-) T lymphocytes are an independent predictor of progression-free survival in patients with metastatic breast cancer during the course of chemotherapy. Cancer Immunol Immunother. 2013:62:1123-30.

47. Mhawech-Fauceglia P, Wang D, Ali L, Lele S, Huba MA, Liu S, Odunsi K. Intraepithelial T cells and tumor-associated macrophages in ovarian cancer patients. Cancer Immun. 2013;13:1.

48. Colovai Al, Liu Z, Ciubotariu R, Lederman S, Cortesini R, Suciu-Foca N. Induction of xenoreactive CD4+ T-cell anergy by suppressor CD8+CD28- T cells. Transplantation. 2000;69:1304-10.

49. Wang RF. CD8+ regulatory $T$ cells, their suppressive mechanisms, and regulation in cancer. Hum Immunol. 2008a;69(11):811-4.

50. Filaci G, Suciu-Foca N. CD8_ T suppressor cells are back to the game: are they players in autoimmunity? Autoimmun Rev. 2002;1:279-83.

51. Suciu-Foca N, Cortesini R. Central role of ILT3 in the T suppressor cell cascade. Cell Immunol. 2007;248:59-67.

52. Sarantopoulos S, Lu L, Cantor H. Qa-1 restriction of CD8_ suppressor T cells. J Clin Invest. 2004;114:1218-21.

53. Jiang $H$, Chess $L$. An integrated view of suppressor $T$ cell subsets in immunoregulation. J Clin Invest. 2004;114:1198-208.

54. Kiniwa Y, Miyahara Y, Wang HY, Peng W, Peng G, Wheeler TM, et al. CD8+ Foxp3+ regulatory $T$ cells mediate immunosuppression in prostate cancer. Clin Cancer Res. 2007b;13:6947-58.

55. Endharti AT, Rifa IM, Shi Z, Fukuoka Y, Nakahara Y, Kawamoto Y, et al. Cutting edge: CD8+CD122+ regulatory T cells produce IL-10 to suppress IFN-gamma production and proliferation of CD8+ T cells. J Immunol. 2005; 175:7093-7.

56. Wang RF. CD8+ regulatory T cells, their suppressive mechanisms, and regulationin cancer. Hum Immunol. 2008b;69(11):811-4.

57. Peng G, Wang HY, Peng W, Kiniwa Y, Seo K, Wang R-F. Tumor-infiltrating gamma-delta $T$ cells suppress $T$ and dendritic cell function via mechanisms controlled by a unique toll like receptor signaling pathway. Immunity. 2007; 27:334-48.

58. Rosser EC, Mauri C. Regulatory B cells: origin, phenotype, and function. Immunity. 2015;42(4):607-12.

59. Wąsik M, Nazimek K, Bryniarsk K. Regulatory B cell phenotype and mechanism of action - the impact of stimulating conditions: immune functions of regulatory B cells. Immunol Microbiol. 2018;62(8):485-96.

60. Mizoguchi A, Mizoguchi E, Takedatsu H, Blumberg RS, Bhan AK. Chronic intestinal inflammatory condition generates IL-10-producing regulatory B cell subset characterized by CD1d upregulation. Immunity. 2002;16(2): 219-30.

61. van de Veen W, Stanic B, Wirz OF, Jansen K, Globinska A, Akdis M. Role of regulatory $B$ cells in immune tolerance to allergens and beyond. J Allergy Clin Immunol. 2016:138(3):654-65.

62. He Y, Qian H, Liu Y, Duan L, Li Y, Shi G. The roles of regulatory B cells in cancer. J Immunol Res. 2014;2014:215471.

63. Schwartz M, Zhang Y, Rosenblatt JD. B cell regulation of the anti-tumor response and role in carcinogenesis. J Immunother Cancer. 2016:4:40.

64. Zhang Y, Gallastegui N, Rosenblatt JD. Regulatory B cells in anti-tumor immunity. Int Immunol. 2015b;27(10):521-30.

65. Zhang X, Deriaud E, Jiao X, Braun D, Leclerc C, Lo-Man R. Type I interferons protect neonates from acute inflammation through interleukin 10producing B cells. J Exp Med. 2007;204(5):1107-18.

66. Lenert $P$, Brummel R, Field EH, Ashman RF. TLR-9 activation of marginal zone $B$ cells in lupus mice regulates immunity through increased IL-10 production. J Clin Immunol. 2005;25(1):29-40.

67. Tadmor T, Zhang Y, Cho H-M, Podack ER, Rosenblatt JD. The absence of B lymphocytes reduces the number and function of T-regulatory cells and enhances the anti-tumor response in a murine tumor model. Cancer Immunol Immunother. 2011;60(5):609-19.

68. Nova-Lamperti E, Fanelli G, Becker PD, Chana P, Elqueta R, Dodd PC, et al IL-10-produced by human transitional B-cells down-regulates CD86 expression on B-cells leading to inhibition of CD4+T-cell responses. Sci Rep. 2016:6:20044 
69. Khan AR, Hams E, Floudas A, Sparwasser T, Weaver CT, Fallon PG. PD-L1hi B cells are critical regulators of humoral immunity. Nat Commun. 2015;6:5997.

70. Lindner S, Dahlke K, Sontheimer K, Hagn M, Kaltenmeier C, Barth TFE, et al. Interleukin 21-induced granzyme B-expressing B cells infiltrate tumors and regulate T cells. Cancer Res. 2013;73(8):2468-79.

71. Olkhanud PB, Damdinsuren B, Bodogai M, Gress RE, Sen R, Wejksza K, et al. Tumor-evoked regulatory $B$ cells promote breast cancer metastasis by converting resting $\mathrm{CD}^{+} \mathrm{T}$ cells to T-regulatory cells. Cancer Res. 2011; 71(10):3505-15.

72. Han $\mathrm{S}$, Feng $\mathrm{S}$, Ren $\mathrm{M}, \mathrm{Ma}$ E, Wang $\mathrm{X}, \mathrm{Xu} \mathrm{L}$, et al. Glioma cell-derived placental growth factor induces regulatory B cells. Int J Biochem Cell Biol. 2014:57:63-8.

73. Mielle J, Audo R, Hahne M, Macia L, Combe B, Morel J, et al. IL-10 producing $B$ cells ability to induce regulatory $T$ cells is maintained in rheumatoid arthritis. Front Immunol. 2018:9:961.

74. Bodogai M, Lee Chang C, Wejksza K, Lai J, Merino M, Wersto RP, et al. AntiCD20 antibody promotes cancer escape via enrichment of tumor-evoked regulatory B cells expressing low levels of CD20 and CD137L. Cancer Res. 2013;73(7):2127-38.

\section{Publisher's Note}

Springer Nature remains neutral with regard to jurisdictional claims in published maps and institutional affiliations.

Ready to submit your research? Choose BMC and benefit from:

- fast, convenient online submission

- thorough peer review by experienced researchers in your field

- rapid publication on acceptance

- support for research data, including large and complex data types

- gold Open Access which fosters wider collaboration and increased citations

- maximum visibility for your research: over $100 \mathrm{M}$ website views per year

At BMC, research is always in progress.

Learn more biomedcentral.com/submissions 